\title{
HOW TO RANK TOURIST DESTINATIONS: A LITERATURE REVIEW
}

\author{
Sraboni Bagchi ${ }^{* 1} \square$ (D) K. M. Sharf Uddin $2 \square$ \\ ${ }^{1}$ Lecturer, Department of Tourism and Hospitality Management, Pabna University of science and Technology, \\ Pabna, Bangladesh. \\ ${ }^{2}$ Associate Professor, Department of Management, Islamic University, Kushtia, Bangladesh.
}

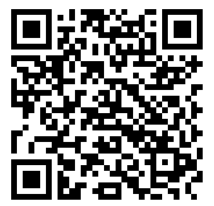

Received 5 August 2021

Accepted 20 August 2021

Published 31 August 2021

\section{CorrespondingAuthor}

Sraboni Bagchi, sraboniiu73@gmail.com DOI

10.29121/granthaalayah.v9.i8.2021. 4178

Funding: This research received no specific grant from any funding agency in the public, commercial, or not-for-profit sectors.

Copyright: (C) 2021 The Author(s). This is an open access article distributed under the terms of the Creative Commons Attribution License, which permits unrestricted use, distribution, and reproduction in any medium, provided the original author and source are credited.

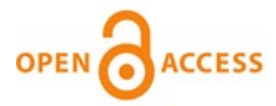

\section{ABSTRACT}

Tourism is the most prominent service industry and one of the world's fastest-growing businesses. One of the most immediate issues in the tourist business is assessing and evaluating tourism destinations. Due to the wide variety of variations across tourism sites, comparing them is a challenging process. This study focuses on various MultiCriteria Decision-Making methods which can be used for assessing and ranking tourist destinations. Although we discovered a number of MCDM techniques for evaluating tourism destinations, they are not extensively employed. So far, the major reasons have been recognized as a lack of knowledge of the procedures, a lack of understanding of their implications, difficulties collecting data, a lack of interest, etc. The purpose of this review article is to give an overview of several MCDM approaches and their implications for ranking tourism destinations. Based on a review of relevant works of literature, this paper describes the phases, strengths, and limits of several MCDM approaches that will be beneficial in deciding which method to employ for evaluating tourism destinations.

Keywords: Tourism, Tourism Destinations, Service Industry, Ranking Methods, MCDM

\section{INTRODUCTION}

Tourism is a significant part of the world economy and is a fast-growing industry in many nations. For the last few decades, tourism has become one of the significant forces for economic growth in many developing and developed countries. Luo et al. (2016) The tourism industry creates a wide range of economic opportunities and employs many people in various sectors. Tourism boosts the revenues of the economy, creates thousands of employments, enhances a country's infrastructure, and promotes cross-cultural engagement. Millions of people's lives are being improved by tourism, and entire towns are being transformed. In the global economy, total international tourist arrivals grew 5\% in 2018 to reach the 1.4 billion marks. At the same time, tourism-related export earnings have increased by $4 \%$ over the previous year to USD 1.7 trillion. (UNWTO 2019).

Recently, it is found that tourism can provide a significant contribution to the nation's economy. Travel \& Tourism is one of the world's largest sectors, supporting 330 million jobs and generating 10.3\% of global GDP in 2019 (WTTC report 2020). Even some countries' economy entirely dependent on their tourism. Tourism is considered one of the biggest service industries in the Turkish economy Önder et al. (2013). The contribution of travel and tourism to GDP in Macau SAR, China in 2019, is $91.3 \%$ (USD 48,915.5 MN) of the total 
economy. The job contribution of travel and tourism is $65.5 \%$ of overall employment. And $81.3 \%$ of overall exports (USD 36,961.4 MN) are invested by international visitors (WTTC 2020).

One of the most immediate issues in the tourism sector is assessing and ranking the tourism destination. Deciding on a suitable travel destination is a complicated procedure, and selecting a suitable approach is not a simple task. In the tourism context, competitiveness is defined as the capacity of tourist destinations to attract travelers and investment (e.g., infrastructure and tourist equipment), which impacts the arrival of visitors, increases employment, and the average expenditure of tourists. This last indicator tracks the economic impact of tourism on local residents and providers of services León Santiesteban and Leyva López (2017). The concept of the attractiveness of destinations (tourism attractiveness) is one of the most frequent issues studied in the theory of tourism and its adjacent disciplines in recent decades Butowski (2018). However, the use of tourist destination ranking is relatively less used as the television industry uses its ranking system (TRP or Television rating point) for determining various rates relating to that industry. Specifically, every tourist has an individual opinion about tourist center selection. Therefore, the following factors have been considered: accessible transportation, cost, belief and doctrines from history and culture, natural beauty, and entertainment Göksu and Kaya (2014). Despite the fact that several ranking methods for tourist destinations have been discovered, they are not widely used. The main reasons, so far identified, include lack of understanding of the methods, lack of understanding their implication, difficulty to collect data, lack of interest, and so on. This paper will summarize the ideas of scholars based on a study of the relevant works of literature from the aspects of exploring different Multi-Criteria Decision Making (MCDM) methods, provide a brief overview of each method, and eventually include the implications of using the ranking methods. The aim of this research is to provide a quick summary of each method, and to explain how these methods may be used to rank tourist destinations.

\section{METHODOLOGY}

This paper will review several articles, books, journals, and other authentic sources to explore various MCDM ranking methods used to evaluate a tourist destination. The current research is based on secondary information. This research looks at several Multi-Criteria Decision Making (MCDM) Methods for ranking tourism locations. The major objective of this research paper is to provide a general overview of various ranking methods and their importance in deciding on a tourism location.

\section{MULTI-CRITERIA DECISION MAKING (MCDM) METHODS}

Multi-criteria decision-making is an operation research sub-discipline that explicitly analyzes several factors in decision-making scenarios. Multiple criteria must generally be examined in making decisions, whether in our daily lives or in our professional life Gülsün et al. (2017). In real life, MCDM issues are quite prevalent. A typical MCDM problem has a number of alternatives to consider and a set of criteria to use to evaluate them. Each criterion has a performance value assigned to each option, and these values may be used to evaluate and rank the alternatives

Karande et al. (2016). At present, the tourism sector is evaluated as a multi-criteria 
group decision-making issue which is concerned with (a) the exploration of the whole alternatives, (b) the identification of the selection criteria, (c) the assessment of the criteria weights along with the performance ratings of alternatives by individual decision-makers, (d) the aggregation of the criteria weights and alternative ratings in order to generate the overall performance index for each alternative across the whole criteria and (e) the selection of the most suitable alternative for a particular situation Wibowo and Deng (2012). MCDM methods can be categorized in a variety of ways by different authors. Hwang and Yoon created a fundamental categorization in 1981. Based on diverse purposes and data groupings, Hwang and Yoon (1981) divide MCDM techniques into two categories: MultiPurpose Decision Making (MPDM) and Multi-Quality Decision Making (MQDM) Arslan (2017). The most commonly used MCDM methods are Value-based methods (AHP, TOPSIS, SMARTS), Superiority methods (ELECTRE, PROMETHEE), Interactive methods (PRIAM, STEM) and other methods Göksu and Kaya (2014). Zardari et al. (2015) have identified three major categories of MCDM approaches, which are expressed as simple, original, and differentiated methods in the form of an up-todate categorization Arslan (2017).

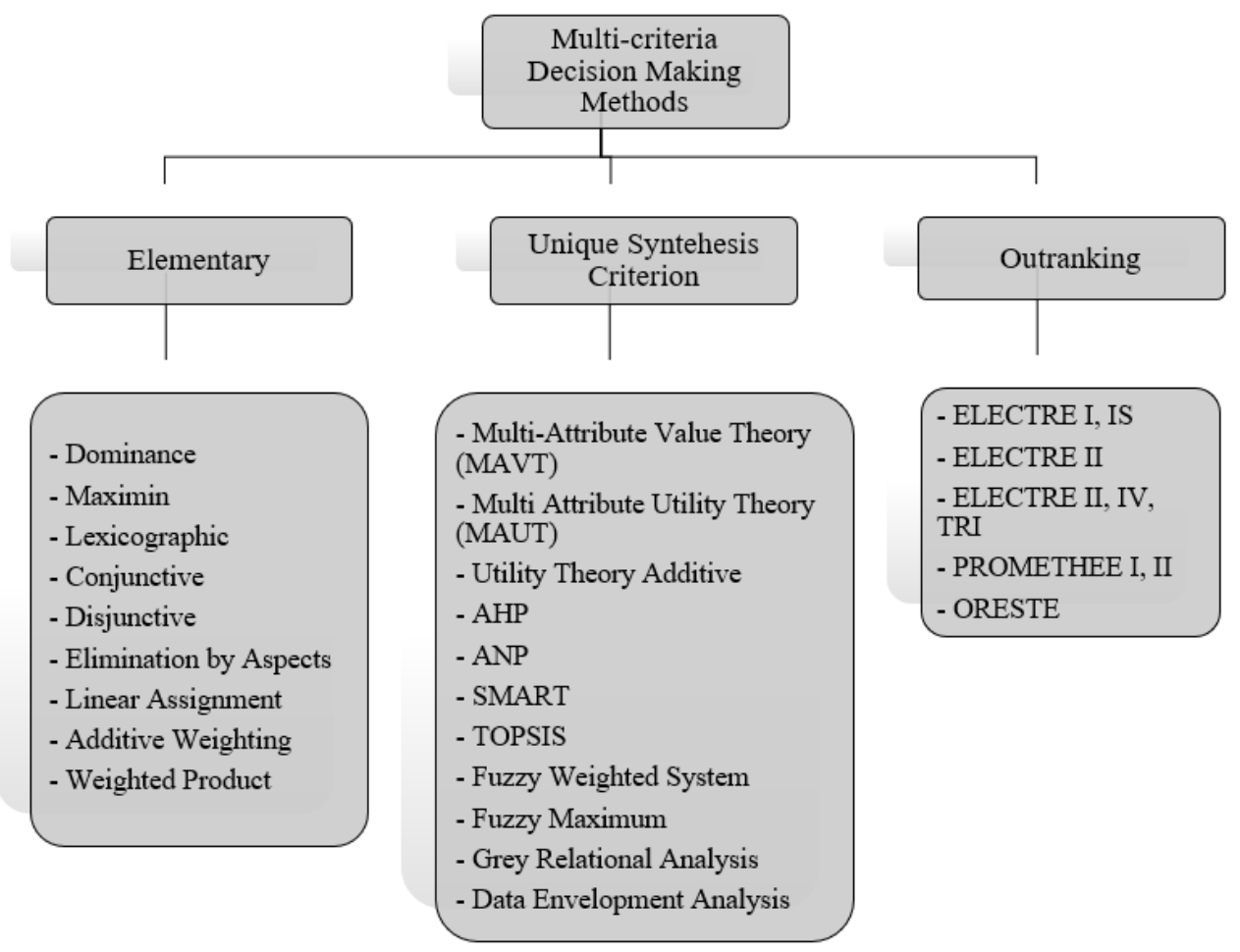

Figure 1 Classification of MCDM methods Zardari et al. (2015)

\section{RANKING METHODS AND RESPECTIVE OVERVIEW}

Destination attractiveness has been one of the most often studied topics in tourism theory and related subjects (tourism attractiveness). One of the decisionmaking difficulties that needs be thoroughly studied in order to select the best alternative among popular choices is destination selection Ali et al. (2012). Several Multi-Criteria Decision-Making (MCDM) approaches assist tourists in selecting the 
best choice from the multiple options available by ranking them. In recent decades, a set of multi-criteria decision-making tools have been intensively applied to the evaluation of tourist attractiveness Butowski (2018). In this study, eight MCDM approaches such as; AHP, Fuzzy AHP, TOPSIS, ELECTRE, PROMETHEE, SMART, GRA and ANP are briefly examined in order to synthesize the opinions of many experts.

\section{1) Analytical Hierarchy Process (AHP)}

The Analytical Hierarchy Process (AHP) method is a classical multi-criteria decision-making tool developed by the American Mathematician T. L. Saaty in the 1970s, and it has been extensively studied and refined since then $(1980,1982,1987$, 1995, and 2008) Butowski (2018). The Analytic Hierarchy Process (AHP) is a qualitative method of weighing alternatives by examining key factors. It's a valuable and effective MCDM method for studying complex topics, emphasizing both mathematics and psychology. By reducing tough decisions to a series of simple pairwise comparisons and rankings, then synthesizing the results, the AHP method facilitates arriving at the best decision and provides a clear rationale for the choices made Ali et al. (2012). With the aid of the AHP approach, travelers may easily make a selection among all the options. All aspects that influence decision-making are organized into a tree hierarchy and given weights in the AHP technique. The weight determines the priority of each alternative for the overall goal. The AHP technique relies heavily on pairwise comparisons to weight criteria and indicators. The AHP constructs a pairwise comparison matrix for each level in the hierarchy using a discrete scale ranging from 1 to 9. Ruano (2018). In defining problems and pairwise comparisons, an order is required in applying AHP to determine the relationships in the structure. The hierarchical structure is depicted in a tree diagram that contains goals (problem objectives to be sought for a solution), criteria, sub-criteria, and alternatives Dharmanto et al. (2019). The analytical hierarchy process (AHP) is to create a hierarchical structure based on the topic. Goals, criteria, alternatives, and their interrelationships should all be visible. Calculating the weight of measures and sub-criteria, calculating the weight of other options, calculating the final points of alternatives, and examining the logical consistency of judgments are all parts of the analytical hierarchy process Nekooee et al. (2011).

\section{2) Fuzzy Analytic Hierarchy Process (FAHP)}

The FAHP technique is an extension of AHP that combines the Fuzzy and AHP approaches for dealing with uncertain situations. The Fuzzy Analytic Hierarchy Process (F-AHP) integrates fuzzy theory with the basic Analytic Hierarchy Process (AHP), which was developed by Saaty Saaty (1980). Fuzzy Analytic Hierarchy Process (FAHP) is a novel fuzzy systematic method for evaluating criteria that integrates a fuzzy approach with Analytic Hierarchy Process Ali et al. (2012). Because many criteria involve using fuzzy numbers, Fuzzy-AHP is a method of producing AHP that can handle fuzzy judgments. In reality, the fuzzy AHP approach is an enhanced analytical decision-making tool derived from the AHP. In the vast majority of circumstances, decision-makers are unable to assess ambiguous desires. On the other hand, fuzzy AHP approaches remove these issues by employing fuzzy comparison ratios. Göksu and Kaya (2014). Because fuzziness is a common element in decision-making problems, the FAHP approach was designed to address this issue in practical situations. Compared to AHP, which analyzes relative weights with crisp numbers, fuzzy AHP effectively depicts human ideas with the ambiguity of real- 
world decision-making situations Lee et al. (2013). The Fuzzy-AHP is a frequently used MCDM approach for deciding on the best places to visit. It involves generating decisions based on several variables that represent tourist preferences. Fuzzy AHP employs a variety of scales in its applications. Converting each relation between criteria into a Triangular Fuzzy Number (TFN) and estimating the degree of possibility are the two critical components of the FAHP method. The procedure concludes with selecting a set of criteria to be used in the final assessment and ranking. Saifullah (2019). Triangular Fuzzy Number (TFN) is a frequently used approach characterized by its conceptual and computational simplicity. It is the most often used approach for defining fuzzy number memberships among the various forms Rekik et al. (2016).

\section{3) Technique for Order Performance by Similarity to Ideal Solution (TOPSIS)}

TOPSIS is a multi-criteria decision analysis approach that was first introduced by Ching-Lai Hwang and Yoon in 1981 Hwang and Yoon (1981) and then improved by Yoon (1987) and Hwang, Lai, and Liu in 1993 Hwang et al. (1981), (Liu, 1993). TOPSIS is a commonly used numerical approach of multi-criteria decision-making that relies on computer assistance and a basic mathematical model. This methodology helps to quantify relative performance in a simple mathematical form and assess the preference values of the alternatives for visitors to rank them when rating tourist destinations. TOPSIS is a multiple-criteria approach for selecting solutions from a limited number of options. The primary notion is that the chosen alternative should be the closest to the positive ideal solution while being the furthest away from the negative ideal solution. Ilban and Yildirim (2017). Positive ideal solutions maximize benefits while minimizing costs, whereas negative ideal solutions enhance costs while minimizing benefits. It is presumptively assumed that each criterion should be maximized or decreased. TOPSIS is a simple and effective method for rating several potential solutions based on how near they are to the ideal answer Önder et al. (2013). TOPSIS makes full use of quality information to assess all the alternatives properly to rank them, and one of the preferences of TOPSIS is that pairwise comparisons are maintained a strategic distance from.

\section{4) The ELECTRE Method}

Elimination Et Choix Traduisant la Realité (Elimination Et Choice Translating Reality), abbreviated as ELECTRE, is a multi-criteria decision-making method used to evaluate some alternatives in any vital sector, such as tourist destination. ÉLECTRE is a multi-criteria decision analysis approach that was originated in the mid-1960s in Europe Wikipedia (2019). ELECTRE methods date back to 1965 when they were first proposed by Bernard Roy and his colleagues at SEMA, a European consulting firm. The term "outranking relations" is used in this strategy. Furthermore, this strategy is more than a solution; it is a philosophy of decision support, which Roy discusses in detail (1991) Eren and Özarı (2016). ELECTRE is a component of the MCDM techniques, which are quantitative techniques that allow the aggregation of several assessment criteria to choose amongst a collection of options Botti et al. (2020). The ELECTRE approach is commonly categorized as an outranking decision-making approach. Using the ELECTRE methodology, outranking relationships between the various options (Tourist destinations) can be 
created León Santiesteban and Leyva López (2017). The ELECTRE approach is divided into two parts: (i) the creation of outranking relations between two alternatives using a combination of a concordance index and a discordance index, and (ii) using these connections to generate recommendations for choice alternatives. Botti et al. (2020). Despite the advantages of assessing the superiority relationship of the alternatives, the ELECTRE technique has the limitations of establishing the criterion weights randomly or subjectively and not measuring the performance scores of the alternatives Öztürk et al. (2018).

\section{5) Preference Ranking Organization Method for Enrichment Evaluations (PROMETHEE)}

The PROMETHEE approach is one of the most widely used Multi-Criteria Decision Analysis (MCDA) methods in tourist research. The PROMETHEE I (partial ranking) and II (complete ranking) were developed by J.P. Brans and Mareschal in the 1980s. The same authors proposed in 1988 the visual interactive module GAIA, which is providing a marvelous graphical representation supporting the methodology. In 1992 and 1994, they suggested two nice extensions: PROMETHEE V (MCDA including segmentation constraints) and PROMETHEE VI (representation of the human brain) Mareschal (2005). Due to the enormous number of factors, the structure of choice issues has become more complicated in recent years. Decisionmakers must consider many parameters during this procedure. With several decision-makers and different criteria, the PROMETHEE technique solves complex and ambiguous choice issues. It also deals with ranking issues when there is no way to compare alternatives. They are made up of an outranking relation, a preference connection between alternatives based on multiple criteria. Rekik et al. (2016). PROMETHEE uses partial aggregation and a pairwise comparison of different actions to determine if one action outranks or not the others under particular conditions. Bottero et al. (2018).

\section{6) Simple Multi-Attribute Rating Technique (SMART)}

SMART is a multi-attribute decision-making approach that uses multi-attribute utility measurement in decision making was created by Edward in 1977 Sihotang et al. (2021). SMART is a basic approach that assigns weights to each of the criteria in order to represent their relative relevance in determining the most suitable alternative. SMART may be used for any number of options or criteria in the tourism sector for evaluating tourist destinations. The drawback of SMART is that its priority and score results differ from those of AHP. Kasie (2013). In reality, this is the simplest MCDM method for responding to decision makers' urgent requirements where the attributes are generally independent, that is, the decision maker's preference (or sentiments) for the value of one attribute is unaffected by the values of the other attributes Fishburn (1976). One of the significant features of this method which is very helpful, is that, when additional options or criteria are added to an existing comparison, any subsequent assessments do not have to start over from the beginning but may instead build on the past results Valiris et al. (2005a) .

\section{7) Grey Relational Analysis (GRA)}

The Grey Relational Analysis (GRA), which is a part of the Gray System Theory, was originally presented by professor Julong Deng, a faculty member at Hua Chung University of Science and Technology in Thailand, in 1982 Akpinar and GERŞIL (2021). Grey relation analysis (GRA) is a method to make decisions in circumstances where there are several criteria by ranking them according to their relational grade. The measurement of shifting relations between two systems or elements that occur 
in a system over time is referred to as a "grey relation." The method of analysis is known as "grey relation analysis," and it analyzes the relationships between items based on the degree of similarity or difference in development patterns among these elements Guo and Sun (2016). GRA addresses MCDM issues by aggregating all of the performance criterion values examined for each alternative into a single value. It reduces the original issue to a single-criterion judgment. Following the GRA method, multi-criteria options may be easily compared Y. Kuo et al. (2008). GRA is a wellknown method for ranking, decision-making, and performance evaluation, and it is a typical MCDM strategy for tackling multidimensional challenges. Grey relation analysis (GRA) is used to analyze and rank tourist destinations when the sample size is small and the sample distribution is unknown.

\section{8) Analytic Network Process (ANP)}

Thomas L. Saaty developed the analytic network process (ANP), a more general variation of the Analytic Hierarchy Process (AHP) in multi-criteria decision analysis, and explains the significance weights of the possibilities. In essence, ANP constructs the problem as a network, whereas AHP constructs it as a hierarchy. (Rekik et al., 2016). In the ANP method, a decision-making issue is split down into numerous levels, and the sum of these levels forms a network. The ANP approach is a valuable tool for combining qualitative and quantitative data. The ANP technique, on the other hand, was chosen because it considers the links between the criteria and hence provides more realistic results. Öztürk et al (2018). This method is a two-part coupling. The first one is a control hierarchy or network of criteria and sub-criteria that manages interactions. The second is an interconnected network of effects between components and clusters Reza and Majid (2013). The ANP technique, like the AHP technique, uses pairwise comparisons of the alternatives to determine the weights of the structure's components and, eventually, to rank them in the decisionmaking.

\section{DISCUSSION}

Tourism has evolved into one of the fastest-growing sectors of the economy, creating employment, driving exports, and generating wealth for many nations worldwide. One of the most challenging difficulties confronting today's tourists is determining how to evaluate and rank tourism destinations and decide what elements impact their decisions. Destination selection is one of the decision-making difficulties that should be thoroughly explored to select the best option from several options Ali et al. (2012). This study tries to help the tourists figure out the best way and choose the best alternative from many possibilities and rank tourist locations. Selecting an ideal vacation location is complex, and establishing a suitable approach for successful tourism destination evaluation is no simple undertaking. A large body of literature discusses various research methodologies used to assess and select tourism destinations Guo and Sun (2016). Several approaches known as Multiple Criteria Decision Making (MCDM) methods have been presented to aid decisionmakers in rating options. Choosing an MCDM ranking technique is difficult due to the variety of accessible approaches. This paper discusses the overview of eight multi-criteria decision-making techniques such as AHP, Fuzzy AHP, TOPSIS, ELECTREE, PROMETHEE, SMART, ANP and GRA which can be used for evaluating and rating tourism locations. Some of the techniques may already be well-known to the general audience. Other methodologies were simply taken from the field of 
industrial research and adapted to the tourist industry. Some are still in the developmental phases. Following the examination of the above MCDM techniques, a quick summary of these methods is provided in Table 1 , which will be useful in deciding which methods will be used in assessing and rating tourism destinations. The procedures, benefits, and limits of these eight techniques are briefly described in the table below, which will aid in determining which way will be easier to use and which will be more difficult in terms of ranking tourist destinations. The basic approach in each of these methods is to define the problem, identify the alternatives, select the MCDM method for the assessment procedure, then use the selected MCDM method to solve the problem and arrive at the best option.

\begin{tabular}{|c|c|c|c|c|c|c|}
\hline MCDM methods & & Stages of the Method & Strengths & & Limitations & References \\
\hline $\begin{array}{l}\text { Analytical Hierarchy } \\
\text { Process (AHP) }\end{array}$ & $\begin{array}{l}4 . \\
5 .\end{array}$ & $\begin{array}{l}\text { Determining decision } \\
\text { hierarchy with } \\
\text { Attributes (criteria) and } \\
\text { Alternatives } \\
\text { Determining pairwise } \\
\text { comparisons of } \\
\text { attributes and } \\
\text { alternatives } \\
\text { Determine the weights, } \\
\text { the Maximum Eigen } \\
\text { Value (max), and the C.I. } \\
\text { (Consistency Index) } \\
\text { Compute the value of } \\
\text { C.R (Consistency Ratio) } \\
\text { normalize the weights } \\
\text { and find out the best } \\
\text { alternative }\end{array}$ & 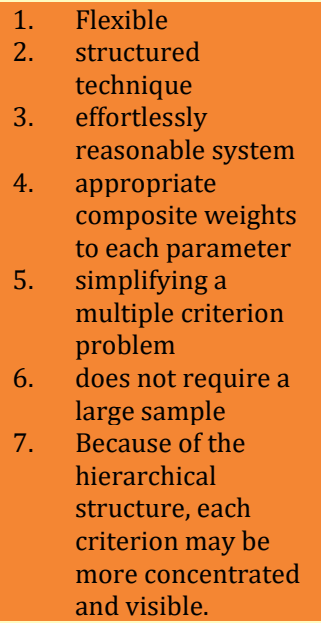 & 2. & $\begin{array}{l}\text { The challenge } \\
\text { of allocating } \\
\text { weights } \\
\text { becomes more } \\
\text { complicated } \\
\text { when more } \\
\text { decision- } \\
\text { makers are } \\
\text { involved. } \\
\text { can't unravel } \\
\text { non-straight } \\
\text { models } \\
\text { When goals and } \\
\text { options are } \\
\text { interconnected, } \\
\text { a hazardous } \\
\text { situation } \\
\text { emerges. }\end{array}$ & $\begin{array}{l}\text { Moktadir M et al. } \\
\text { (2017) } \\
\text { Crisostomo\& } \\
\text { Gustilo(2019) } \\
\text { Božic (2016) } \\
\text { Božić (2018) } \\
\text { Socaciu et al. (2016) } \\
\text { Kumar (2017a) } \\
\text { Karthikeyan et al. } \\
\text { (2016) }\end{array}$ \\
\hline $\begin{array}{l}\text { Fuzzy Analytic Hierarchy } \\
\text { Process (FAHP) }\end{array}$ & & $\begin{array}{l}\text { Define the Problem } \\
\text { Create a comparison } \\
\text { matrix } \\
\text { Checking for } \\
\text { consistency } \\
\text { Set up Triangular Fuzzy } \\
\text { Number (TFN) } \\
\text { Calculate the fuzzy } \\
\text { vector's weight value. } \\
\text { Ranking and selection of } \\
\text { decisions }\end{array}$ & $\begin{array}{l}\text { 1. } \begin{array}{l}\text { The advanced } \\
\text { analytical decision- } \\
\text { making method }\end{array} \\
\text { 2. } \begin{array}{l}\text { handle fuzzy } \\
\text { decisions }\end{array} \\
\text { 3. leals with } \\
\text { ambiguous or not } \\
\text { well-defined } \\
\text { situations. } \\
\text { 4. } \begin{array}{l}\text { scientific } \\
\text { framework } \\
\text { collect the } \\
\text { qualitative and } \\
\text { quantitative data } \\
\text { effectively }\end{array}\end{array}$ & $\begin{array}{l}1 . \\
2 .\end{array}$ & $\begin{array}{l}\text { Fuzziness } \\
\text { complex } \\
\text { calculation } \\
\text { Difficulty when } \\
\text { confronted } \\
\text { with a } \\
\text { problematic } \\
\text { issue. }\end{array}$ & $\begin{array}{l}\text { Dwi Putra et al. (2018) } \\
\text { Lee et al. (2013) } \\
\text { Ali et al. (2012) } \\
\text { Göksu and Kaya } \\
\text { (2014) } \\
\text { Saifullah (2019) }\end{array}$ \\
\hline $\begin{array}{l}\text { Technique for Order } \\
\text { Performance by } \\
\text { Similarity to Ideal } \\
\text { Solution (TOPSIS) }\end{array}$ & 1. & $\begin{array}{l}\text { To establish the decision } \\
\text { matrix for the ranking } \\
\text { To calculate the } \\
\text { normalized decision } \\
\text { matrix } \\
\text { To calculate the } \\
\text { weighted normalized } \\
\text { decision matrix using its } \\
\text { associated weights. } \\
\text { To determine the } \\
\text { positive and negative } \\
\text { ideal solutions } \\
\text { To calculate the } \\
\text { separation measures } \\
\text { from the positive ideal } \\
\text { solution }\end{array}$ & $\begin{array}{l}\text { 1. The use of a basic } \\
\text { ranking system } \\
\text { 2. uses all of the } \\
\text { information that has } \\
\text { been given to them. } \\
\text { 3. The technique is } \\
\text { logical and } \\
\text { understandable } \\
\text { the notion is } \\
\text { expressed } \\
\text { mathematically in a } \\
\text { straightforward } \\
\text { manner. } \\
\text { The computing } \\
\text { procedure is } \\
\text { relatively easy, and }\end{array}$ & 1. & $\begin{array}{l}\text { The approach is } \\
\text { based on } \\
\text { Euclidean } \\
\text { distance, in } \\
\text { theory; } \\
\text { therefore, } \\
\text { negative and } \\
\text { positive } \\
\text { numbers have } \\
\text { no impact on } \\
\text { computations. } \\
\text { The findings } \\
\text { are heavily } \\
\text { influenced by a } \\
\text { significant } \\
\text { divergence of }\end{array}$ & $\begin{array}{l}\text { Göksu and Kaya } \\
\text { (2014) } \\
\text { Siksnelyte et al. (2018) } \\
\text { Jato-Espino et al. } \\
\text { (2014) } \\
\text { Shih Shih et al. (2007) } \\
\text { Emre Boran et al. } \\
\text { (2009) }\end{array}$ \\
\hline
\end{tabular}




\begin{tabular}{|c|c|c|c|c|c|c|c|}
\hline & 6. & $\begin{array}{l}\text { To calculate the relative } \\
\text { closeness of the } \\
\text { alternative. The index } \\
\text { value ranges from } 0 \text { to } 1 \text {. } \\
\text { The greater the index } \\
\text { value, the more } \\
\text { important the options } \\
\text { are. }\end{array}$ & & $\begin{array}{l}\text { the results are } \\
\text { obtained quite } \\
\text { rapidly. }\end{array}$ & & $\begin{array}{l}\text { one indication } \\
\text { from the } \\
\text { optimum } \\
\text { result. }\end{array}$ & \\
\hline The ELECTRE Method & $\begin{array}{l}7 . \\
8 .\end{array}$ & $\begin{array}{l}\text { Construction of } \\
\text { Decision Matrix } \\
\text { Calculation of the } \\
\text { Normalized Decision } \\
\text { Matrix } \\
\text { Calculation of the } \\
\text { Weighted Normalized } \\
\text { Decision Matrix } \\
\text { Determination of the } \\
\text { Concordance and } \\
\text { Discordance Sets } \\
\text { Construction of } \\
\text { Concordance and } \\
\text { Discordance Matrix } \\
\text { Determine the } \\
\text { Concordance } \\
\text { Dominance and } \\
\text { Discordance } \\
\text { Dominance Matrix } \\
\text { Determine the } \\
\text { Aggregate Dominance } \\
\text { Matrix } \\
\text { Eliminate the less } \\
\text { favorable alternative } \\
\text { and rank them }\end{array}$ & 1. & $\begin{array}{l}\text { provide a sensible } \\
\text { and straightforward } \\
\text { computation } \\
\text { examining the } \\
\text { superiority relation } \\
\text { of the alternatives } \\
\text { Decision Support } \\
\text { Systems (DSS) } \\
\text { method }\end{array}$ & 2. & $\begin{array}{l}\text { determining } \\
\text { the criteria } \\
\text { weights } \\
\text { randomly or } \\
\text { subjectively } \\
\text { not calculating } \\
\text { the } \\
\text { performance } \\
\text { scores of the } \\
\text { alternatives } \\
\text { Less adaptable }\end{array}$ & $\begin{array}{l}\text { Eren and Özarı (2016) } \\
\text { Nawir et al. (2017) } \\
\text { Öztürk et al. (2018) } \\
\text { Eren and Özarı, (2016) }\end{array}$ \\
\hline The PROMETHEE Method & 2. & $\begin{array}{l}\text { Obtain an assessment } \\
\text { matrix and compare } \\
\text { them pairwise, taking } \\
\text { into account each and } \\
\text { every criterion. } \\
\text { Assigning a preference } \\
\text { function with values } \\
\text { ranging from } 0 \text { to } 1 \\
\text { depending on the pair } \\
\text { difference } \\
\text { creating a global matrix } \\
\text { and calculating the rank } \\
\text { by adding the column } \\
\text { that expresses which } \\
\text { option is superior to the } \\
\text { others. }\end{array}$ & 2. & $\begin{array}{l}\text { useful where } \\
\text { several choices are } \\
\text { tough to harmonize } \\
\text { uses both } \\
\text { qualitative and } \\
\text { quantitative data } \\
\text { Calculations can } \\
\text { take into account } \\
\text { uncertain and fuzzy } \\
\text { data. }\end{array}$ & 1. & $\begin{array}{l}\text { The calculation } \\
\text { procedure is } \\
\text { time- } \\
\text { consuming. } \\
\text { Calculations } \\
\text { are quite } \\
\text { difficult. }\end{array}$ & $\begin{array}{l}\text { Brans JP (1985) } \\
\text { Kumar et al. (2017a) } \\
\text { Siksnelyte et al. (2018) } \\
\text { Kumar et al. (2017b) } \\
\text { Amaral and (2014) } \\
\text { Brans and Vincke } \\
\text { (1985) }\end{array}$ \\
\hline $\begin{array}{l}\text { Simple Multi-Attribute } \\
\text { Rating Technique } \\
\text { (SMART) }\end{array}$ & $\begin{array}{l}1 . \\
2 . \\
3 . \\
4 .\end{array}$ & $\begin{array}{l}\text { Identification of } \\
\text { criteria and } \\
\text { alternatives } \\
\text { Give preference weight } \\
\text { to criteria } \\
\text { Normalization of } \\
\text { preference weight } \\
\text { Giving score to } \\
\text { attribute for each } \\
\text { alternative } \\
\text { Calculating or } \\
\text { determining the utility } \\
\text { value } \\
\text { Aggregation of utility } \\
\text { values with preference } \\
\text { weight }\end{array}$ & $\begin{array}{l}1 . \\
2 . \\
3 .\end{array}$ & $\begin{array}{l}\text { Independent of the } \\
\text { alternatives } \\
\text { Simplest method } \\
\text { Values of one } \\
\text { attribute are not } \\
\text { influenced by the } \\
\text { values of others. } \\
\text { No limitation for } \\
\text { attributes or criteria } \\
\text { A good degree of } \\
\text { accuracy }\end{array}$ & 1. & $\begin{array}{l}\text { Priority and } \\
\text { score result is } \\
\text { not equally } \\
\text { consistent with } \\
\text { AHP. } \\
\text { limitations in } \\
\text { the class of } \\
\text { each attribute } \\
\text { consistency } \\
\text { limitation as } \\
\text { compared to } \\
\text { AHP. }\end{array}$ & $\begin{array}{l}\text { Sihotang et al. (2021) } \\
\text { Valiris et al. (2005b) } \\
\text { Kasie (2013) } \\
\text { Fishburn (1976) } \\
\text { Risawandi and Rahim } \\
\text { (2016) }\end{array}$ \\
\hline
\end{tabular}




\begin{tabular}{|c|c|c|c|c|c|}
\hline $\begin{array}{l}\text { Grey Relational Analysis } \\
\text { (GRA) }\end{array}$ & $\begin{array}{l}4 . \\
5 .\end{array}$ & $\begin{array}{l}\text { Preparing data set and } \\
\text { construct decision } \\
\text { matrix } \\
\text { Constructing reference } \\
\text { series and compare } \\
\text { matrix } \\
\text { Normalization process } \\
\text { and constructing } \\
\text { normalization matrix } \\
\text { Constructing absolute } \\
\text { values table } \\
\text { Calculating the grey } \\
\text { relational coefficient for } \\
\text { each alternative } \\
\text { Calculating the grey } \\
\text { relational degree }\end{array}$ & $\begin{array}{l}\text { 1. simplifies and } \\
\text { facilitates the } \\
\text { assessment process } \\
\text { 2. meaningful \& } \\
\text { flexible } \\
\text { 3. easy to compute } \\
\text { and understand } \\
\text { 4. doesn't require } \\
\text { a large sample size }\end{array}$ & $\begin{array}{l}\text { 1. a limited } \\
\text { number of } \\
\text { criteria and } \\
\text { alternatives } \\
2 . \quad \text { poor, } \\
\text { limited, and } \\
\text { unreliable } \\
\text { information } \\
3 . \quad \text { a failure } \\
\text { to look at the } \\
\text { alternative's } \\
\text { outcome } \\
\text { indicators }\end{array}$ & $\begin{array}{l}\text { Pourmohammadi et al. } \\
\text { (2018) } \\
\text { Guo and Sun (2016) } \\
\text { H-H (2002) } \\
\text { Jiang H Lin J-Y (2017) } \\
\text { Akpinar and GERŞIL } \\
\text { (2021) } \\
\text { MT (2015) }\end{array}$ \\
\hline $\begin{array}{l}\text { Analytic Network Process } \\
\text { (ANP) }\end{array}$ & $\begin{array}{l}1 . \\
2 .\end{array}$ & $\begin{array}{l}\text { The problem is defined, } \\
\text { and a decision model is } \\
\text { established } \\
\text { The relationships } \\
\text { between the criteria of } \\
\text { the problem and its sub- } \\
\text { criteria are determined. } \\
\text { Priority vectors are } \\
\text { calculated from pairwise } \\
\text { comparisons between } \\
\text { the criteria. } \\
\text { Consistency analyzes of } \\
\text { comparison matrices } \\
\text { are performed. } \\
\text { Super matrics is created } \\
\text { The best alternative is } \\
\text { chosen. } \\
\text { The best alternative is } \\
\text { chosen. }\end{array}$ & $\begin{array}{l}\text { 1. A useful tool } \\
\text { for prediction } \\
2 . \quad \text { provides more } \\
\text { realistic results } \\
\text { 3. allows the ease } \\
\text { of usage of the } \\
\text { qualitative and } \\
\text { quantitative data } \\
\text { together. } \\
\text { 4. using inner } \\
\text { dependency of } \\
\text { elements }\end{array}$ & $\begin{array}{l}\text { The complexity } \\
\text { of deciding on a } \\
\text { final decision }\end{array}$ & $\begin{array}{l}\text { Reza and Majid (2013) } \\
\text { Öztürk et al. (2018) } \\
\text { Hadiwijaya et al. } \\
\text { (2018) }\end{array}$ \\
\hline
\end{tabular}

Aside from these eight MCDM techniques, there are a few more that aren't covered in this research, such as; PRIAM, STEM, VIKOR, DEA, TODIM, SAW and other MCDM techniques. All of these MCDM methodologies can also be used for tourist destination evaluation. Tourists can analyze and evaluate tourist attractions using any of these MCDM methodologies. As previously stated, MCDM is based on the comparison of alternatives (available options), criteria (measuring parameters), and their combinations. All of the strategies that aid in achieving an ideal condition of outcome are essentially a mix of these key elements. Despite the numerous benefits of the above-mentioned MCDM methods in Table 1, visitors seldom employ these approaches due to restrictions such as difficulties of understanding the approaches, a lack of comprehension of their implications, a lack of interest, and so on. For a proper appraisal of tourism destinations, these constraints must be overcome. This research is entirely based on the literature and focuses on eight MCDM techniques, which are briefly summarized in Table 1 . Despite the fact that a thorough overview of these approaches was provided, a checklist of these eight MCDM methods is presented here based on Table 1 and the preceding discussion. 


\begin{tabular}{|c|c|c|c|c|c|c|c|c|}
\hline & АнP & $\begin{array}{c}\text { FUZZY } \\
\text { AHP }\end{array}$ & TOPSIS & ELECTREE & PROMETHEE & SMART & ANP & GRA \\
\hline Pairwise comparison of alternatives & $\sqrt{ }$ & $\sqrt{ }$ & $\sqrt{ }$ & & $\sqrt{ }$ & & $\sqrt{ }$ & \\
\hline Calculation of weights of each alternative & $\sqrt{ }$ & $\sqrt{ }$ & & & & & $\sqrt{ }$ & \\
\hline Compute consistency ratio & $\sqrt{ }$ & $\sqrt{ }$ & & & & & $\sqrt{ }$ & \\
\hline Triangular Fuzzy Number (TFN) & & $\sqrt{ }$ & & & & & & \\
\hline Calculate Normalized decision matrix & & & $\sqrt{ }$ & $\sqrt{ }$ & & & & $\sqrt{ }$ \\
\hline Decision Support Systems (DSS) method & & & & $\sqrt{ }$ & & & & \\
\hline No limitation for attributes or criteria & & & & & & $\sqrt{ }$ & & \\
\hline It doesn't require a large sample size & $\sqrt{ }$ & & $\sqrt{ }$ & & & & & $\sqrt{ }$ \\
\hline Determine the positive and negative ideal solutions & & & $\sqrt{ }$ & & & & & \\
\hline Collect both qualitative and quantitative data & & $\sqrt{ }$ & & & $\sqrt{ }$ & & $\sqrt{ }$ & \\
\hline Provides more realistic results & & & & & & & $\sqrt{ }$ & \\
\hline Determination of the Concordance and Discordance Sets & & & & $\sqrt{ }$ & & & & \\
\hline Handle uncertain, fuzzy and ambiguous decisions & & $\sqrt{ }$ & & & $\sqrt{ }$ & & & \\
\hline Calculations are quite difficult. & & $\sqrt{ }$ & & $\sqrt{ }$ & $\sqrt{ }$ & & & \\
\hline Easy to compute and understand & & & $\sqrt{ }$ & & & $\sqrt{ }$ & & $\sqrt{ }$ \\
\hline Independent of the alternatives & & & & & & $\sqrt{ }$ & & \\
\hline The complexity of deciding on a final decision & & & & & & & $\sqrt{ }$ & \\
\hline
\end{tabular}

\section{CONCLUSION}

Based on the summary and review of related literature about evaluating tourism destinations, it is viewed that multi-criteria decision-making (MCDM) methods are feasible assessment scale for ranking tourism destinations by comparing the results of many options. In the tourism sector, there is a lot of potential for using these ranking systems to rate tourist destinations. This research examines eight MCDM techniques for evaluating tourism locations. It is evident from this study that the Fuzzy AHP, ELECTREE, and PROMETHEE techniques are more challenging than the others, and they are used to calculate uncertain, fuzzy, and ambiguous data. On the other hand, AHP, TOPSIS, SMART, ANP, and GRA are less difficult than the previous three. According to the literature study, the AHP technique is the most common ranking system, whereas SMART is the easiest one. These eight techniques may all be used to rank tourist destinations. This study will enrich the existing literature related to MCDM methods. In rating tourism sites, the study highlights the use of MCDM methods. Furthermore, MCDM approaches are briefly examined, along with their unique characteristics. The discussion claims that employing these methodologies, tourist destination research has provided numerous outcomes and provided a solid platform for future study, based on a review of relevant literature. Only the theoretical elements of some MCDM ranking methods are covered in this study. This study can be useful for the researchers to conduct further study in a ranking system. It will also help researchers to pursue their studies related to ranking alternatives in different fields. 


\section{REFERENCES}

Akpinar, M. E., \& GERŞİL, M. (2021). AHP and Grey Relations Analysis Based Sightseeing Boat Selection for Summer Tourism Activities. Journal of Marine and Engineering Technology (JOINMET), 1(1), 34-41. Retrieved from https://journals.subu.edu.tr/index.php/joinmet/article/view/153

Ali, N. H., Sabri, I. A., Noor, N. M., \& Ismail, F. (2012). Rating and Ranking Criteria for Selected Islands using Fuzzy Analytic Hierarchy Process (FAHP). International Journal of Applied Mathematics and Informatics, 6(1), 57-65. Retrieved from https://www.researchgate.net/profile/Ily-AhmadSabri/publication/334784372_Rating_and_Ranking_Criteria_for_Selected_I slands_using_Fuzzy_Analytic_Hierarchy_Process_FAHP/links/5d413ec5a6f dcc370a6f0ea0/Rating-and-Ranking-Criteria-for-Selected-Islands-using-

Fuzzy-Analytic-Hierarchy-Process-FAHP.pdf

Amaral, T. M., \& Costa, A. P. C. (2014). Improving decision-making and management of hospital resources: An application of the PROMETHEE II method in an Emergency Department. Operations Research for Health Care, 3(1), 1-6. Retrieved from https://doi.org/10.1016/j.orhc.2013.10.002

Arslan, H. M. (2017). CURRENT CLASSIFICATION OF MULTI CRITERIA DECISION ANALYSIS METHODS AND PUBLIC SECTOR IMPLEMENTATIONS. In Current Debates in Public Finance, Public Administration, \& Environmental Studies (pp. 241-261).

Bottero, M., D'Alpaos, C., \& Oppio, A. (2018). Multicriteria evaluation of urban regeneration processes: An application of PROMETHEE method in northern Italy. Advances in Operations Research, 2018, 1-12. Retrieved from https://doi.org/10.1155/2018/9276075.

Botti, L., Petit, S., \& Zhang, L. (2020). Strategic decision concerning tourist origins portfolio: A decision process based on the ELECTRE method and applied to French Polynesia. Tourism Economics, 26(5), 830-843. Retrieved from https://doi.org/10.1177/1354816619891323

Božic, S., Spasojević, B., Vujičić, M. D., \& Stamenkovic, I. (2016). Exploring The Motives Of Religious Travel By Applying The Ahp Method - A Case Study of Vujan Monastery (Serbia). International Journal of Religious Tourism and Pilgrimage, 4(iv), 1-13. Retrieved from https://doi.org/10.15308/Sitcon2016-116-121

Božić, S., Vujičić, M. D., Kennell, J., Besermenji, S., \& Solarević, M. (2018). Sun, sea and shrines: Application of analytic hierarchy process (AHP) to assess the attractiveness of six cultural heritage sites in Phuket (Thailand). Geographica Pannonica, 22(2), 121-138. Retrieved from https://doi.org/10.5937/22-16983

Brans, J. P., \& Vincke, P. (1985). A Preference Ranking Organization Method (The PROMETHEE Method for Multiple Criteria Decision Making). Management Science, 31(6), 647-656. Retrieved from https://doi.org/10.1287/mnsc.31.6.647 
Brans JP, V. P. (1985). Note-A Preference Ranking Organisation Method: The PROMETHEE Method for Multiple Criteria Decision-Making). Manag Sci, 31, 647-656. Retrieved from https://doi.org/10.1287/mnsc.31.6.647

Butowski, L. (2018). An integrated AHP and PROMETHEE approach to the evaluation of the attractiveness of European maritime areas for sailing tourism. Moravian Geographical Reports, 26(2), 135-148. Retrieved from https://doi.org/10.2478/mgr-2018-0011

Crisostomo, A. S. I., \& Gustilo, R. C. (2019). Tourism: Asian Country Ranking Using Analytic Hierarchy Process. 2019 IEEE 11th International Conference on Humanoid, Nanotechnology, Information Technology, Communication and Control, Environment, and Management, HNICEM 2019, 1-7. Retrieved from https://doi.org/10.1109/HNICEM48295.2019.9072840

Dharmanto, A., Komariah, N. S., Handayani, M., Suminar, R., \& Untari, D. T. (2019). Analysis of tourism preferences in choosing online-base travel agents in Indonesia. International Journal of Scientific and Technology Research, 8(12), 3761-3763. Retrieved from http://repository.ubharajaya.ac.id/id/eprint/3596

Dwi Putra, M. S., Andryana, S., Fauziah, \& Gunaryati, A. (2018). Fuzzy Analytical Hierarchy Process Method to Determine the Quality of Gemstones. Hindawi. Advances in Fuzzy Systems, 2018, 1-6. Retrieved from https://doi.org/10.1155/2018/1989423

Emre Boran, F., Genç, S., \& Akay, D. (2009). A multi-criteria intuitionistic fuzzy group decision making for supplier selection with TOPSIS method. Expert Systems with Applications, 36(8), 11363-11368. Retrieved from https://doi.org/10.1016/j.eswa.2009.03.039

Eren, Ö., \& Özarı, Ç. (2016). EVALUATING ECOTOURISM DESTINATION USING ELECTRE AND PROMETHEE DECISION MODEL. International Research Journal of Natural and Applied Sciences, 3(7), 246-260. Retrieved from https://www.researchgate.net/profile/Cigdem-

Oezari/publication/311589182_EVALUATING_ECOTOURISM_DESTINATIO N_USING_ELECTRE_AND_PROMETHEE_DECISION_MODEL/links/584fd4e5 08aed95c250b4bcb/EVALUATING-ECOTOURISM-DESTINATION-USINGELECTRE-AND-PROMETHEE-DECISION-MODEL.pdf

Fishburn, P.. (1976). Noncompensatory preferences. Synthese, 33, 393-403. Retrieved from https://doi.org/10.1007/BF00485453

Göksu, A., \& Kaya, S. E. (2014). RANKING OF TOURIST DESTINATIONS WITH MULTICRITERIA DECISION MAKING METHODS IN BOSNIA AND HERZEGOVINA. Economic Review - Journal of Economics and Business, XII (2), 91-103. Retrieved from http://hdl.handle.net/10419/193841

Gülsün, B., Yıldız, S., \& Yılmaz, B. (2017). MULTI-CRITERIA DECISION MAKING AND THE CHOICE OF HOTELS IN TOURISM SECTOR. International Journal of Business Tourism and Applied Sciences (IJBTS), 5(2), 44-50. Retrieved from http://www.ijbtsjournal.com/images/main_1366796758/IJBTS\%205(2_7)\%20BAHADIR\% 20G\%C3\%9CLS\%C3\%9CN\%20MU17.pdf 
Guo, X., \& Sun, Z. (2016). A Novel Evaluation Approach for Tourist Choice of Destination Based on Grey Relation Analysis. Scientific Programming, 1-10. Retrieved from https://doi.org/10.1155/2016/1812094

H-H., W. (2002). A comparative study of using grey relational analysis in multiple attribute decision making problems. Qual Eng., 15(2), 209-217. Retrieved from https://doi.org/10.1081/QEN-120015853

Hadiwijaya, N. A., Hamdani, H., Syafrianto, A., \& Tanjung, Z. (2018). The Decision Model for Selection of Tourism Site Using Analytic Network Process Method. I.J. Intelligent Systems and Applications, 9, 23-31. Retrieved from https://doi.org/10.5815/ijisa.2018.09.03

Hwang, C.L.; Lai, Y.J.; Liu, T. Y. (1993). A new approach for multiple objective decision making. Computers and Operational Research, 20(8), 889-899. Retrieved from https://doi.org/10.1016/0305-0548(93)90109-V

Hwang, C.L.; Yoon, K. (1981). Multiple Attribute Decision Making: Methods and Applications. In New York: Springer-Verlag. Retrieved from https://doi.org/10.1007/978-3-642-48318-9

Ilban, M. O., \& Yıldırım, H. H. (2017). Determination of tourism activities of the world's best tourism destinations using the multi-criteria decision-making method. Cogent Social Sciences, 3, 1-16. Retrieved from https://doi.org/10.1080/23311886.2017.1301763

Jato-Espino, D., Castillo-Lopez, E., \& Rodriguez-Hernandez, Jorge Canteras-Jordana, J. C. (2014). A review of application of multi-criteria decision making methods in construction. Automation in Construction, 45, 151-162. Retrieved from https://doi.org/10.1016/j.autcon.2014.05.013

Jiang H, Lin J-Y, J. P. (2017). Using Grey Relational Analysis with Entropy to predict the international financial center of China. J Syst Sci Inform., 5(1), 88-96. Retrieved from https://doi.org/10.21078/JSSI-2017-088-09

Karande, P., Zavadskas, E. K., \& Chakraborty, S. (2016). A study on the ranking performance of some MCDM methods for industrial robot selection problems. International Journal of Industrial Engineering Computations, 7, 399-422. Retrieved from https://doi.org/10.5267/j.ijiec.2016.1.001

Karthikeyan, R., Venkatesan, K. G. S., \& Chandrasekar, A. (2016). A Comparison of Strengths and Weaknesses for Analytical Hierarchy Process. Journal of Chemical and Pharmaceutical Sciences, 9(3), 12-15.

Kasie, F. M. (2013). Combining Simple Multiple Attribute Rating Technique and Analytical Hierarchy Process for Designing Multi-Criteria Performance Measurement Framework. Global Journal of Researches in Engineering Industrial Engineering Volume, 13(1), 15-30. Retrieved from https://engineeringresearch.org/index.php/GJRE/article/view/747

Kumar, A., Sah, B., Singh, A. R., Deng, Y., He, X., Kumar, P., \& Bansal, R. C. (2017a). A review of multi criteria decision making (MCDM) towards sustainable renewable energy development. Renewable and Sustainable Energy Reviews, 69, 596-609. Retrieved from https://doi.org/10.1016/j.rser.2016.11.191

Kumar, A., Sah, B., Singh, A. R., Deng, Y., He, X., Kumar, P., \& Bansal, R. C. (2017b). A review of multi criteria decision making (MCDM) towards sustainable 
renewable energy development. Renewable and Sustainable Energy

Reviews, 69, 596-609. Retrieved from

https://doi.org/10.1016/j.rser.2016.11.191

Lee, S. K., Mogi, G., \& Hui, K. S. (2013). A fuzzy analytic hierarchy process (AHP)/data envelopment analysis (DEA) hybrid model for efficiently allocating energy $R \& D$ resources: In the case of energy technologies against high oil prices. Renewable and Sustainable Energy Reviews, 21, 347-355. Retrieved from https://doi.org/10.1016/j.rser.2012.12.067

León Santiesteban, M., \& Leyva López, J. C. (2017). A multicriteria decision aid for evaluating the competitiveness of tourist destinations in the Northwest of Mexico. Turismo y Sociedad, 21, 51-67. Retrieved from https://doi.org/10.18601/01207555.n21.03

Luo, Y., Chen, Y., \& Zheng, W. (2016). A Literature Review on Evaluating Tourism Destinations. International Conference on Information System and Management Engineering, 329-334. Retrieved from https://doi.org/10.5220/0006449903290334

Mareschal, B. (2005). PROMETHEE methods. In International Series in Operations Research and Management Science (Vol. 78, Issue January, pp. 163-195). Retrieved from https://doi.org/10.1007/0-387-23081-5_5

Maulana, M. A., Habib, M., Setyanto, A., \& Oktavia. (2018). Tourism Trend Mapping Based on Social Media Using SAW Algorithm. Journal of Physics: Conference Series, 1-8. Retrieved from https://doi.org/10.1088/17426596/1140/1/012041

Moktadir M, A., Rahman, T., \& Sultana, R. (2017). Selection of Best Supplier by Using AHP Tool for Managing Risk Factors in Logistics: A Case of Leather Products Industry. Industrial Engineering \& Management, 06(04), 1-7. Retrieved from https://doi.org/10.4172/2169-0316.1000232

MT., P. (2015). Multi optimization of process parameters by using grey relation analysis-a review. Int J Adv Res IT Eng., 4(6), 1-15. Retrieved from https://www.indianjournals.com/ijor.aspx?target=ijor:ijarie \&volume=4\&i ssue $=6 \&$ article $=001$

Nawir, S., Manda, R., Rahman, T., \& Fatmah, A. U. (2017). Implementation of ELECTRE Method in Determining the Priority of a Sustainable Tourist Attraction Development in Gorontalo Regency. 1st Annual Applied Science and Engineering Conference, 1-9. Retrieved from https://doi.org/10.1088/1742-6596/755/1/011001

Nekooee, Z., Karami, M., \& Fakhari, I. (2011). Assessment and Prioritization of Urban Tourist Attractions Based on Analytical Hierarchy Process (AHP) (A Case Study of Birjand, Iran). Journal of Applied Business and Economics, 12(4), 122-134. Retrieved from http://www.nabusinesspress.com/JABE/nekooee_abstract.html

Önder, E., Fatih, Y. B., \& Özdemir, M. (2013). Multi Criteria Decision Making Approach for Evaluating Tourism Destinations in Turkey. ACADEMIC JOURNAL OF TOURISM AND MANAGEMENT RESEARCHES, 1, 1-15. Retrieved from

https://papers.ssrn.com/sol3/papers.cfm?abstract_id=2382498 
Öztürk, H., Pekel, E., \& Elevli, B. (2018). Using ANP and ELECTRE Methods for Supplier Selection: Cable Industry Application. Sakarya University Journal of Science, 22(5), 1190-1198. Retrieved from https://doi.org/10.16984/saufenbilder.315330

Pourmohammadi, K., Shojaei, P., Rahimi, H., \& Bastani, P. (2018). Evaluating the health system financing of the Eastern Mediterranean Region ( EMR ) countries using Grey Relation Analysis and Shannon Entropy. Cost Effectiveness and Resource Allocation, 16(31), 1-9. Retrieved from https://doi.org/10.1186/s12962-018-0151-6

Rekik, R., Kallel, I., Casillas, J., \& Alimi, A. M. (2016). Using Multiple Criteria Decision Making Approaches to Assess the Quality of Web Sites. International Journal of Computer Science and Information Security ((IJCSIS), 14(7), 747-761.

Reza, S., \& Majid, A. (2013). Ranking Financial Institutions Based on of Trust in online banking Using ARAS and ANP Method. International Research Journal of Applied and Basic Sciences, 6(4), 415-423. Retrieved from https://irjabs.com/files_site/paperlist/r_1703_131014114007.pdf

Risawandi, \& Rahim, R. (2016). Study of the Simple Multi-Attribute Rating Technique for Decision Support. International Journal of Scientific Research in Science and Technology (IJSRST), 2(6), 491-494. Retrieved from https://doi.org/10.31227/osf.io/xnhtj

Ruano, M. (2018). Decision Making within the Tourism Industry with AHP: Determining key influential factors affecting foreign visitors' decision to revisit Belize , Central America.

Saaty, T. L. (1980). The Analytic Hierarchy Process. McGraw-Hill, New York, USA.Retrieved from https://doi.org/10.21236/ADA214804

Saifullah, S. (2019). Fuzzy-AHP approach using Normalized Decision Matrix on Tourism Trend Ranking based-on Social Media. Jurnal Informatika, 13, 1623. Retrieved from https://doi.org/10.26555/jifo.v13i2.a15268

Sari, N. (2021). Implementation of the AHP-SAW Method in the Decision Support System for Selecting the Best Tourism Village. Jurnal Teknik Informatika CIT Medicom, 13(1), 23-32. Retrieved from https://www.medikom.iocspublisher.org/index.php/JTI/article/view/51

Shih Shih, H., Jyh Shyur, H., \& Stanley Lee, E. (2007). An extension of TOPSIS for group decision making. Mathematical and Computer Modelling, 45(7-8), 801-813. Retrieved from https://doi.org/10.1016/j.mcm.2006.03.023

Sihotang, D. M., Hidayanto, A. N., Abidin, Z., \& Diana, E. (2021). SMART method for recommender system towards smart tourism and green computing. IOP Conference Series: Earth and Environmental Science, 700(1), 1-10. Retrieved from https://doi.org/10.1088/1755-1315/700/1/012017

Siksnelyte, I. ., Zavadskas, E. K. ., Streimikiene, D. ., \& Sharma, D. (2018). An Overview of Multi-Criteria Decision-Making Methods in Dealing with Sustainable Energy Development Issues. Energies, 11(10), 2754. Retrieved from https://doi.org/10.3390/en11102754

Socaciu, L., Giurgiu, O., Banyai, D., \& Simion, M. (2016). PCM Selection Using AHP Method to Maintain Thermal Comfort of the Vehicle Occupants. Energy 


$\begin{array}{lcccc}\text { Procedia, } & \text { 85, } & 489-497 . & \text { Retrieved } & \text { from } \\ \text { https://doi.org/10.1016/j.egypro.2015.12.232 } & & \end{array}$

Sunarti, Sundari, J., Anggraeni, S., Siahaan, F. B., \& Jimmi. (2018). Comparison Topsis And Saw Method In The Selection Of Tourism Destination In Indonesia. 2018 Third International Conference on Informatics and Computing (ICIC), 1-6. Retrieved from https://doi.org/10.1109/IAC.2018.8780550

Valiris, G., Chytas, P., \& Glykas, M. (2005a). Making decisions using the balanced scorecard and the simple multi-attribute rating technique. Performance Measurement and Metrics, 6(3), 159-171. Retrieved from https://doi.org/10.1108/14678040510636720

Valiris, G., Chytas, P., \& Glykas, M. (2005b). Making decisions using the balanced scorecard and the simple multi-attribute rating technique. Performance Measurement and Metrics, 6(3), 159-171. Retrieved from https://doi.org/10.1108/14678040510636720

Wibowo, S., Deng, H. (2012). Intelligent decision support for effectively evaluating and selecting ships under uncertainty in marine transportation. Expert Systems with Applications, 39(8), 6911-6920. Retrieved from https://doi.org/10.1016/j.eswa.2012.01.003

Wikipedia. (2019). ÉLECTRE. The Free Encyclopedia. Retrieved from https://en.wikipedia.org/wiki/ELECTRE

Y. Kuo, T. Yang, and G. W. H. (2008). The use of grey relational analysis in solving multiple attribute decision-making problems. Comput. Ind. Eng. Retrieved from https://doi.org/10.1016/j.cie.2007.12.002

Yoon, K. (1987). A reconciliation among discrete compromise situations. Journal of the Operational Research Society, 38(3), 277-286. Retrieved from https://doi.org/10.1057/jors.1987.44

Zardari, N. H., Ahmed, K., Shirazi, S. M., \& Yusop, Z. Bin. (2015). Weighting Methods and their Effects on Multi-Criteria Decision Making Model Outcomes in Water Resources Management. In SpringerBriefs in Water Science and Technology (pp. 7-67). Retrieved from https://link.springer.com/bookseries/11214 